\title{
Epstein-Barr Virus in Oral Cavity Squamous Cell Carcinoma of Chilean Patients
} \author{
José Martínez ${ }^{4}$ \\ ${ }^{1}$ Department of Oral Pathology and Oral Medicine, School of Dentistry, University of Chile, Chile \\ ${ }^{2}$ Department of Oncology Surgery, National Institute of Cancer, Chile \\ ${ }^{3}$ Department of Public Health and Epidemiology, University of los Andes, Chile \\ ${ }^{4}$ Virology Program, I.C.B.M., University of Chile, Chile
}

Gina Pennacchiotti ${ }^{1}$, Camila Álvarez ${ }^{1}$, Rodrigo Montes ${ }^{2}$, Marcela Cárcamo $^{3}$, Raúl Sáez $^{1}$ and María

*Corresponding author: Dr. María José Martínez, Virology Program, I.C.B.M., University of Chile, Independencia 1027, Santiago, 8380453, Chile, Tel: +56-2-29786128, Fax: +56-2-29786317

\section{Abstract}

Background: Squamous cell carcinoma is the most frequent malignancy in the oral cavity. Although the role of tobacco and alcohol in the process of carcinogenesis is widely considered, viral participation in carcinogenesis is scarcely studied. Our aim was to detect the Epstein-Barr virus presence in fresh tissue samples from adult patients with oral cavity Squamous Cell Carcinoma and its relationship with clinical and socio-epidemiological variables.

Methods: A cross-sectional study was carried out for two years in all untreated patients derived to the Chilean $\mathrm{Na}-$ tional Cancer Institute. A fresh sample of the tumour was obtained for real time-polymerase chain reaction. Clinical and sociodemographic variables were recorded. To explore statistical associations, the p-value of 0.05 was used.

Results: Twenty-two patients acceded to be enrolled, $54.5 \%$ of men. Fifteen biopsies (68\%) were positive for the Epstein-Barr virus and $56 \%$ were located on the left edge of the tongue. No statistical association was found between the viral presence and the recorded variables. Male sex was associated with alcohol consumption, and the female sex was associated with tongue localization. Our mortality rate was $59 \%$.

Conclusion: This study showed a high prevalence of EBV in fresh Squamous Cell Carcinoma tumour tissue of the oral cavity of Chilean patients and a low survival rate. Oral cavity cancer is not comparable to pharyngeal. The lack of statistical association could be due to the sample size. Consequently, larger and multicentre studies are needed in our region. A worldwide common methodology as well as a new separate classification is desirable.
\end{abstract}

\section{Keywords}

Epstein-Barr virus, Carcinoma, Oral cavity, PCR

\section{Introduction}

Squamous cell carcinoma (SCC) is the most frequent malignancy in the oral cavity and is an important problem for world public health. In the GLOBOCAN report 2012 , there is an annual worldwide incidence estimation of 198,975 cases, including lip, and 97,940 cases were the cause of death [1]. In Europe, an increase incidence trends is reported in Denmark, Netherlands, and Portugal and only in females in Italy and France [2]. In England and Wales the oral SCC records had increased since 2010, although scarce improvement in survival rates has been achieved. The great majority $(91.2 \%)$ of all oral cavity cancers in the audit year 2013-2014 were SCC [3]. This rising incidence trends in Europe contrast with the situation in the US and Canada [2]. In Chile, according to the mortality data from 2000 to 2010, the crude death rate from oral and pharyngeal cancer was estimated in a range from 1.11 to 1.25 per 100,000 inhabitants, the ratio being higher in men than in women; 2.3:1 [4].

As the aetiology of oral cavity SCC is multifactorial, the rate of incidence of this cancer varies widely accord-

Citation: Pennacchiotti G, Álvarez C, Montes R, Cárcamo M, Sáez R, et al. (2020) Epstein-Barr Virus in Oral Cavity Squamous Cell Carcinoma of Chilean Patients. Int J Oral Dent Health 6:106. doi. org/10.23937/2469-5734/1510106

Accepted: January 30, 2020: Published: February 01, 2020

Copyright: (c) 2020 Pennacchiotti G, et al. This is an open-access article distributed under the terms of the Creative Commons Attribution License, which permits unrestricted use, distribution, and reproduction in any medium, provided the original author and source are credited. 
ing to the habits or forms of consumption, whether of tobacco or alcohol, exposure to other risk factors, infection by virus, genetic predisposition of the individual, and possibly others [5]. Although the role of tobacco and alcohol in the process of carcinogenesis is well known, little is known about the participation of viruses in the oral cavity SCC. Viruses, as carcinogens, contribute to a significant proportion of the global burden of cancer since approximately $15 \%$ of all human cancers are attributable to them [6,7]. Serological and epidemiological studies provide evidence of an etiological association between viruses and neoplasms of the head and neck [8]. The Epstein-Barr virus (EBV) has been associated with epithelial and lymphoid cancers, including Nasopharyngeal cancers (NPC), but data has been controversial in the different studies of intraoral tumours $[9,10]$. In UK, EBV is the third cause of cancer-causing infection and is detected in $90 \%$ of NPC [3]. This viral infection is widely distributed in the world, and in Chile, it reaches $76 \%$ seroprevalence in adults [11]. Given that only the role of Human papillomavirus (HPV) has been investigated in Chilean patients with oral cavity SCC and it has been demonstrated in a low percentage of tumours [12], our aim was to extend the viral study to the detection of EBV and explore its relationship with clinical and socio-epidemiological factors in Latin American patients.

\section{Materials and Methods}

A cross-sectional study was approved by the Research and Ethics Committee of the Metropolitan North Health Service and Human Ethics and it was conducted in full accordance with the World Medical Association Declaration of Helsinki. The study was carried out at the Instituto Nacional del Cáncer (INCANCER), and all adult patients, men and women with a clinical and histopathological diagnosis of oral cavity SCC, who came to the centre to be treated and give a written consent, was enrolled for two years.

The inclusion criteria were patients older than 18 years who had not received any previous oncological treatment, under normal physical and mental conditions. A confidential and structured survey was carried out for each patient, in whom sociodemographic data and risk habits were recorded: Sex, age, education, cigarette consumption, alcohol intake, tooth brushing, use of mouthwash, dental prosthesis, number of sexual partners, oral sex practice. Also, the clinical data, anatomic location of the oral cavity SCC, the degree of cancer differentiation, and staging, were recorded.

A fresh sample of the tumour was obtained from each patient during surgery. The tissue of $0.5 \times 0.5$ $\mathrm{cm}$ was excised avoiding necrotic areas. Each sample was transported immediately in a sterile cryotube inside a container at $8{ }^{\circ} \mathrm{C}$ to the Virology Laboratory where they were stored at- $80{ }^{\circ} \mathrm{C}$ for further pro- cessing and analysis. DNA was extracted from each sample and then quantified by spectrophotometry Anthos $2001^{\circledR}$. The obtained extracts were subjected to a Polymerase chain reaction (PCR) for human $\beta$ globin, and those positive samples were subjected to real-time PCR (QR-PCR) for EBV [13]. Briefly, the primers used amplified the BNTp143 region. To the $74 \mathrm{bp}$, the white amplifier was attached to the TM probe: 5'6 FAM-CGC AGG CAC TCG TAC TGC TCGTM -TMR 3, in Thermal Cycler PXEO, 2 (Thermo Electron USA ${ }^{\circledR}$ ) equipment, performing 45 cycles of $95{ }^{\circ} \mathrm{C}, 60$ ${ }^{\circ} \mathrm{C}$, and $72{ }^{\circ} \mathrm{C}$. Positive and negative controls were incorporated in each test. For the statistical analysis, the variables were analysed according to their nature: The qualitative using absolute and relative frequencies, and the quantitative through measures of central tendency and dispersion. The exploration of associations was carried out through Fisher's exact test. A significance level of 0.05 was used. All the analyses were done with the software STATA 14.0.

\section{Results}

A total of 22 patients; 12 (54.5\%) men and 10 (45.5\%) women, gave their consent and were studied. The range of age was from 24 to 82 years with a median of 56 years for the men and 54 years for the women. Less than half of the patients had completed school education. Ten (45.5\%) patients smoked cigarettes, and 11 (50\%) consumed any alcohol, the latter being associated with the man sex characteristic $(p=0.02)$. Sixty-eight per cent of patients performed tooth brushing at least twice a day, $41 \%$ used mouthwash, and $31.8 \%$ had dentures. A total of $63.6 \%$ of the patients declared three or more sexual partners in their life time and $77.3 \%$ have had oral sex. Ten (45.5\%) patients were in stage $\mathrm{T} 1$ or $\mathrm{T} 2$, and three had metastases. The overall rate of death was $59 \%$.

Of the 22 oral cavity SCC biopsies, 12 (54.5\%) were localized in tongue and ten in alveolar ridge or floor of mouth, finding a statistical association between female sex and tongue localization $(p=0.04)$. Half of the tumours were reported by pathologist as "poorly differentiated". Fifteen biopsies (68\%) were positive for EBV. However, no statistical association was found between the viral presence and the clinical or sociodemographic characteristics of the patients. This EBV positive subset had a male/female ratio of $1: 1$, and the average age was 51 years for the positive women and 62 years for the men. The most frequent localization was the left edge of the tongue, with $56 \%$ of EBV positive cases.

\section{Discussion}

We present a long term study involving Latin American patients derived from all the country to the national cancer centre. Even though the number of patients could seem small it has to be considered the highly restricted inclusive criteria and the intraoper- 
Table 1: EBV detection in worldwide oral cavity SCC fresh tissue samples studies.

\begin{tabular}{|l|l|l|l|}
\hline Continent \& Country & Sample & Method & Number (\%) \\
\hline South America & Tumour & RQ-PCR & $15 / 22(68)$ \\
\hline Chile & & & \\
\hline North America & Tumour & RQ-PCR & $2 / 113(1.8)$ \\
\hline USA [15] & & & \\
\hline Europe & Tumour & nPCR & $48 / 65(73.8)$ \\
\hline Hungary [16] & & & \\
\hline Asia & $\begin{array}{l}\text { Cells for } \\
\text { cytobrush }\end{array}$ & PCR & $26 / 89(32.5)$ \\
\hline Thailand [17] & $\begin{array}{l}\text { Tissue } \\
\text { India [18] }\end{array}$ & PCR & $18 / 62(29)$ \\
\hline Yemen [19] & Biopsy & PCR & $44 / 60(73.3)$ \\
\hline
\end{tabular}

$\mathrm{PCR}=$ Polymerase Chain Reaction; RQ-PCR = Real Time Polymerase Chain reaction, $\mathrm{nPCR}=$ Nested Polymerase Chain Reaction.

ative sample take methodology that narrowed the incorporation possibilities. In favour of our results is the balanced and representative group randomly incorporated, as we achieved a group of previously untreated adults, half women, with similar mean age, rate of smokers, oral cavity hygiene and sexual behaviours, as well as in cancer stage and mortality rate. They only differed in alcohol intake and oral cavity tumour localization. Although we found a high prevalence of EBV in oral cavity SCC and a very low two year relative survival, there are very few worldwide studies done in fresh tissue, to compare with (Table 1). Additionally, they are very variable on the geographical region studied, the methodology and the techniques used [14]. Based on sample type and technique used, our results are similar to the Hungarian study, since most of the published studies include paraffin fixed samples, pharyngeal tumours or different oral cavity diseases in their analyses [20-23] On the other hand, conducted a study in oral cavity SCC of the mobile portion of the tongue and did not identify EBV in the analysed samples [10]. So, some considerations should be made in regard of comparing worldwide scientific data. Though, detection of the viral genome by PCR is the most used method in the epidemiological studies, there are variations in the sensitivity of the different protocols; as well it is on the quality of the analysed samples [14]. Particularly, when imbibed paraffin tissue is studied, because enzymes can be inhibited by the chemical solvents. So, methodology unification is imperative.

We found the great majority of the tumours localized in the tongue, as is currently reported [2]. Interestingly, they were associated with woman sex. This result stands in absolute agreement with South American epidemiological data as we are the main country increasing female oropharyngeal cancer [24]. Although is man sex that show a higher global incidence trend, our study revealed an association in between the alcohol intake, a known oral cavity SCC risk factor, and tumours in areas of the oral cavity other than the tongue, with being man. The high consumption of alcohol in our population is worldwide recognized. These results are important in conducting our patients' history and physical examination. Thus, it is necessary to design larger studies in order to clarify the oral cavity SCC profile for each sex in different world regions, as genetic variations and habits changes in the diverse cultures. There is a generalized agreement that more research is needed to determine the extent to which EBV participates in transformation in human malignancies. Especially in epithelial oral cavity cancers were the EBV reaches the human body, infects epithelial and lymphoid cells of the Waldeyer's ring and starts different replicative and latent patterns. This environment favours EBV latent establishment as latent genes are found [25].

Just as there are geographical differences in the EBV rate in oral cavity SCC fresh tissue, we emphasize the need to worldwide separate oral and pharyngeal epidemiological data [2]. There is very little doubt that EBV plays a role in oral cavity SCC and papillomavirus is a fundamental actor in some pharyngeal cancer, so a different view should overcome. We are in front of a double cancer problem with high rates of infection-caused cancer and increasing rates of occidental lifestyle related cancers [24].

\section{Acknowledgements}

The study had the financial support of the Virology Program, Institute of Biomedical Sciences of the Faculty of Medicine of the University of Chile. All authors have no conflict of interest to declare.

\section{References}

1. Ferlay J, Soerjomataram I, Dikshit R, Eser S, Mathers C, et al. (2015) Cancer incidence and mortality worldwide: Sources, methods and major patterns in GLOBOCAN. Int J Cancer 136: 359-386.

2. Braakhuis BJ, Leemans CR, Visser $O$ (2014) Incidence and survival trends of head and neck squamous cell carcinoma in the Netherlands between 1989 and 2011. Oral Oncol 50: 670-675.

3. National Institute for Health and Care Excellence (NICE) (2006) National Collaborating Centre for Cancer. Upper aerodigestive tract cancer.

4. Ramírez V, Vásquez Rozas $P$, Ramírez-Eyraud $P$ (2015) Mortalidad por cáncer oral y faríngeo en Chile, años 2002-2010. Rev Clin Periodoncia Implantol Rehabil Oral 8: 133-138.

5. Das BR, Nagpal JK (2002) Understanding the biology of oral cancer. Med Sci Monit 8: 258-267.

6. Serraino D, Piselli P, Angeletti Cl, Scuderi M, Ippolito G, et al. (2005) Infection with Epstein-Barr virus and cancer: An epidemiological review. J Biol Regul Homeost Agentes 19: 63-70.

7. Parkin DM (2006) The global health burden of infection-associated cancers in the year 2002. Int J Cancer 118: 30303044. 
8. Gillison ML, Shah KV (2001) Human papillomavirus-associated head and neck squamous cell carcinoma: Mounting evidence for an etiologic role for human papillomavirus in a subset of head and neck cancers. Curr Opin Oncol 13: 183-188.

9. Shimakage M, Horii K, Tempaku A, Kakudo K, Shirasaka T, et al. (2002) Association of Epstein-Barr virus with oral cancers. Hum Pathol 33: 608-614.

10. Wilms T, Khan G, Coates PJ, Sgaramella N, Fåhraeus R, et al. (2017) No evidence for the presence of Epstein-Barr virus in squamous cell carcinoma of the mobile tongue. PLoS One 12: e0184201.

11. Luchsinger V, Luzoro A, Martínez MJ (2010) Elevada seroprevalencia de citomegalovirus, virus herpes simplex tipo 1 y virus Epstein Barr en adultos con virus de la inmunodeficiencia humana. Rev Med Chile 138: 809-814.

12. Pennacchiotti G, Sáez R, Martínez MJ (2016) Human papilloma virus prevalence in patients diagnosed with squamous carcinoma oral cavity. Rev Chil Cir 68: 137-142.

13. Watzinger F, Suda M, Preuner S, Baumgartinger R, Ebner K, et al. (2004) Real-time quantitative PCR assays for detection and monitoring of pathogenic human viruses in immunosuppressed pediatric patients. J Clin Microbiol 42 : 5189-5198.

14. Sand L, Jalouli J (2014) Viruses and oral cancer. Is there a link? Microbes and Infect 16: 371-378.

15. Goldenberg D, Benoit NE, Begum S, Westra WH, Cohen $Y$, et al. (2004) Epstein-Barr virus in head and neck cancer assessed by quantitative polymerase chain reaction. Laryngoscope 114: 1027-1031.

16. Kis A, Fehér E, Gáll T, Tar I, Boda R, et al. (2009) Epstein-Barr virus prevalence in oral squamous cell cancer and in potentially malignant oral disorders in an eastern Hungarian population. Eur J Oral Sci 117: 536-540.
17. Acharya $S$, Ekalaksananan $T$, Vatanasapt $P$, Loyha $K$, Phusingha $P$, et al. (2015) Association of Epstein-Barr virus infection with oral squamous cell carcinoma in a case-control study. J Oral Pathol Med 44: 252-257.

18. Jalouli J, Ibrahim SO, Mehrotra R, Jalouli MM, Sapkota D, et al. (2010) Prevalence of viral (HPV, EBV, HSV) infections in oral submucous fibrosis and oral cancer from India. Acta Otolaryngol 130: 1306-1311.

19. Nasher AT, Al-hebshi NN, Al-Moayad EE, Suleiman AM (2014) Viral infection and oral habits as risk factors for oral squamous cell carcinoma in Yemen: A case-control study. Oral Surg Oral Med Oral Pathol Oral Radiol 118: 566-572.

20. Shirin Saravani, Ebrahim Miri-Moghaddam, Nima Sanadgol, Hamideh Kadeh, Mohammad Reza Nazeri (2014) Human herpesvirus-6 and Epstein-Barr virus infections at different histopathological grades of oral squamous cell carcinomas. Int J Prev Med 5: 1231-1238.

21. Sand LP, Jalouli J, Larsson PA, Hirsch JM (2002) Prevalence of Epstein-Barr virus in oral squamous cell carcinoma, oral lichen planus, and normal oral mucosa. Oral Surg Oral Med Oral Pathol Oral Radiol Endod 93: 586-592.

22. Gonzalez-Moles MA, Gutierrez J, Rodriguez MJ, Ruiz-Avila I, Rodriguez-Archilla A (2002) Epstein-Barr virus latent membrane protein-1(LMP) expression in oral squamous cell carcinoma. Laryngoscope 112: 482-487.

23. Yen CY, Lu MC, Tzeng CC, Huang JY, Chang HW, et al. (2009) Detection of EBV infection and gene expression in oral cancer from patients in Taiwan by microarray analysis. J Biomed Biotechnol.

24. Sierra MS, Soerjomataram I, Antoni S, Laversanne M, Piñeros M, et al. (2016) Cancer patterns and trends in Central and South America. Cancer Epidemiol 44: 23-42.

25. Kikuchi K, Inoue H, Miyazaki Y, Ide F, Kojima MY, et al. (2017) Epstein-Barr virus (EBV)-associated epithelial and non-epithelial lesions of the oral cavity. Jpn Dent Sci Rev 53: 95-109. 